\title{
Hubungan Pengetahuan Perawat tentang Komunikasi Terapeutik dengan Kepuasan Pasien di Ruang Cendana Rumah Sakit Tingkat III Wolter Mongisidi
}

\author{
Semuel Stevi Kumajas ${ }^{*}$ \\ 1*. Universitas Pembangunan Indonesia, Jl. R.W. Monginsidi VI No. 129, Kota Manado, Indonesia, 95115 \\ *e-mail: stevikumajas@gmail.com
}

(Received: 27-11-2019; Reviewed: 09-12-2019;Accepted: 30-12-2019)

\begin{abstract}
In everyday life nurses can not be separated from communication activities. Communication is a communication that is very effective in facilitating nurses to carry out their roles and functions properly, usually these activities are related to the psychology profession, medical or nursing health counseling, and alternative clinics, so that communication can function as a therapeutic tool which is then called "therapeutic communication ". With this method, a therapist directs communication so that the patient is confronted with situations and message exchanges that can lead to beneficial social relationships. Nurses as officers who are always in contact with patients must have many skills, one of which is Interpersonal skills, namely skills in communicating with patients (therapeutic). Therapeutic communication is an effective way to change human behavior and is useful in carrying out health services in hospitals, so this communication must be developed continuously (Kario, 2012). The therapeutic relationship between the nurse and the client can be realized by the therapeutic interaction between the two, the interaction must be carried out with the standard stages of the client nurse's therapeutic interaction, that stage is the pre-orientation stage, the orientation phase, the work phase and termination. Measurement of the level of patient satisfaction is absolutely necessary, in an effort to improve the quality of health services. Through these measurements, it can be seen the extent to which the dimensions of quality of health services that have been held can meet patient expectations (Pohan, 2012). In the era of globalization, excellent service is a major element in hospitals and health units. Hospitals are required to provide health services that meet optimal service standards. This type of research is analytic descriptive, the time in August 2019 and the place of research in the Sandalwood Room Level III Wolter Mongisidi Hospital Manado. The statistical test used was Chi Square with a 95\% confidence level if.The results of the study there is a relationship of knowledge about therapeutic communication with patient satisfaction in the Sandalwood Room Level III Wolter Mongisidi Hospital Manado.
\end{abstract}

Keywords: Knowledge, Patient Satisfaction, Therapeutic Communication

\begin{abstract}
Abstrak
Dalam kehidupan sehari-hari perawat tidak bisa lepas dari kegiatan komunikasi. Komunikasi merupakan komunikasi merupakan sarana yang sangat efektif dalam memudahkan perawat melaksanakan peran dan fungsinya dengan baik, biasanya kegiatan tersebut berhubungan dengan profesi psikologi, konseling kesehatan medis atau keperawatan, dan klinik alternatif, sehingga komunikasi dapat berfungsi sebagai alat terapi yang kemudian disebut dengan "komunikasi terapeutik". Dengan metode ini, seorang terapis mengarahkan komunikasi begitu rupa sehingga pasien dihadapkan pada situasi dan pertukaran pesan yang dapat menimbulkan hubungan sosial yang bermanfaat.Perawat sebagai petugas yang selalu berhubungan dengan pasien harus memiliki banyak keterampilan, salah satunya adalah keterampilan Interpersonal, yaitu keterampilan dalam berkomunikasi dengan pasien (terapeutik). Komunikasi terapeutik merupakan cara efektif untuk merubah tingkah laku manusia dan bermanfaat dalam melaksanakan pelayanan kesehatan di rumah sakit, sehingga komunikasi ini harus dikembangkan terus-menerus (Kario, 2012). Hubungan antara perawat dan klien yang terapeutik bisa terwujud dengan adanya interaksi yang terapeutik antara keduanya, interaksi tersebut harus
\end{abstract}


dilakukan dengan tahapan-tahapan baku interaksi terapeutik perawat klien, tahapan itu merupakan tahap pre orientasi, tahap orientasi, tahap kerja dan terminasi. Pengukuran tingkat kepuasan pasien mutlak diperlukan, dalam upaya peningkatan mutu pelayanan kesehatan. Melalui pengukuran tersebut, maka dapat diketahui sejauh mana dimensi-dimensi mutu pelayanan kesehatan yang telah diselenggarakan dapat memenuhi harapan pasien (Pohan, 2012).Pada era globalisasi, pelayanan prima merupakan elemen utama di rumah sakit dan unit kesehatan.Rumah sakit dituntut untuk memberikan pelayanan kesehatan yang memenuhi standar pelayanan yang optimal.Jenis penelitian yaitu deskriptif analitik,waktu pada bulan Agustus 2019 dan tempat penelitian di di Ruang Cendana RS Tingkat III Wolter Mongisidi Manado. Uji statistik yang digunakan adalah Chi Square dengan derajat kepercayaan 95\% bila $\alpha<0,05$ hasil penelitian terdapat hubungan pengetahuan tentang komunikasi terapeutik dengan kepuasan pasien di Ruang Cendana RS Tingkat III Wolter Mongisidi Manado.

Kata Kunci : Kepuasan Pasien, Komunikasi Terapeutik, Pengetahuan

\section{Pendahuluan}

Pelayanan keperawatan merupakan bagian yang tak terpisahkan dari pelayanan kesehatan baik di rumah sakit maupun fasilitas pelayanan kesehatan lainnya, keperawatan merupakan bagian yang integral dari pelayanan kesehatan maka pelayanan keperawatan yang berkualitas merupakan salah satu indikator untuk menilai mutu suatu pelayanan kesehatan (Kepmenkes RI , 2016) .

Rumah sakit merupakan salah satu sarana pelayanan kesehatan yang sering dimanfaatkan oleh masyarakat dalam mencari bantuan terhadap permasalahan kesehatan. Menjadi hal penting dalam pelayanan kesehatan rumah sakit mengenai prilaku perawat, ataupun kurangnya informasi yang diberikan oleh perawat terhadap masalah kesehatan yang dihadapi pasien, ataupun sikap tidak komunikatif perawat pada saat memberikan pelayanan keperawatan, dan sikap kurang memperhatikan keluhan yang disampaikan pasien (Aswar, 2012) .

Dalam kehidupan sehari-hari perawat tidak bisa lepas dari kegiatan komunikasi. Komunikasi merupakan komunikasi merupakan sarana yang sangat efektif dalam memudahkan perawat melaksanakan peran dan fungsinya dengan baik, biasanya kegiatan tersebut berhubungan dengan profesi psikologi, konseling kesehatan medis atau keperawatan, dan klinik alternatif, sehingga komunikasi dapat berfungsi sebagai alat terapi yang kemudian disebut dengan "komunikasi terapeutik". Dengan metode ini, seorang terapis mengarahkan komunikasi begitu rupa sehingga pasien dihadapkan pada situasi dan pertukaran pesan yang dapat menimbulkan hubungan sosial yang bermanfaat (Endang, 2015).

Perawat sebagai petugas yang selalu berhubungan dengan pasien harus memiliki banyak keterampilan, salah satunya adalah keterampilan Interpersonal, yaitu keterampilan dalam berkomunikasi dengan pasien (terapeutik). Komunikasi terapeutik merupakan cara efektif untuk merubah tingkah laku manusia dan bermanfaat dalam melaksanakan pelayanan kesehatan di rumah sakit, sehingga komunikasi ini harus dikembangkan terus-menerus (Kario, 2012). Hubungan antara perawat dan klien yang terapeutik bisa terwujud dengan adanya interaksi yang terapeutik antara keduanya, interaksi tersebut harus dilakukan dengan tahapan-tahapan baku interaksi terapeutik perawat klien, tahapan itu merupakan tahap pre orientasi, tahap orientasi, tahap kerja dan terminasi (Stuart, 2014).

Kepuasan pasien tergantung pada kualitas pelayanan. Pelayanan adalah semua upaya yang dilakukan karyawan untuk memenuhi keinginan pelanggannya dengan jasa yang akan diberikan. Suatu pelayanan dikatakan baik oleh pasien, ditentukan oleh kenyataan apakah jasa yang diberikan bisa memenuhi kebutuhan pasien, dengan menggunakan persepsi pasien tentang pelayanan yang diterima (memuaskan atau mengecewakan, juga termasuk lamanya waktu pelayanan).Kepuasan dimulai dari penerimaan terhadap pasien dari pertama kali datang, sampai pasien meninggalkan rumah sakit.

Jurnal penelitian Sarkasih tahun 2016 Dosen Fakultas Keperawatan Universitas Indonesia dengan judul hubungan pengetahuan perawat tentang komunikasi teraupetik dengan kepuasan pasien di RS Cipto terdapat hubungan yang signifikan. Dimana nilai pvalue $=0,001 \alpha<0,05$ sehingga terdapat hubungan komunikasi teraupetik perawat dengan tingkat kepuasan pasien

Ketidakpuasan pasien diartikan sama dengan keluhan terhadap rumah sakit, berikut pelayanan yang dilakukan oleh tenaga kesehatannya (dokter, perawat, apoteker, psikolog dan lainnya) dan struktur sistem perawatan kesehatan (biaya, sistem asuransi, kemampuan dan prasarana pusat kesehatan dan lain-lain). Pasien mengharapkan interaksi yang baik, sopan, ramah, nyaman dengan tenaga kesehatan, sehingga kompetensi, kualifikasi serta kepribadian yang baik dari pelayan kesehatan, faktor utama dalam menentukan kepuasan pasien antara lain lengkapnya peralatan medik, bangunan dan fasilitas rumah sakit yang memadai, kelengkapan sarana pendukung dalam pelayanan.

Di Rumah Sakit, sumberdaya yang paling banyak menyumbang sebagai pendukung kepuasan kepada pasien adalah perawat. Perawat memberikan hubungan besar untuk menentukan kualitas pelayanan. Perawat sebaiknya 
mempunyai standar dalam melakukan pelayanan terhadap pasien, terutama jika karakteristik masing-masing serta pasien yang menjadi tanggung jawab di kelas perawatan yang diampunya semakin beragam, apakah ada perbedaan cara memberikan pelayanan dengan melihat karakteristik pasien yang berbeda, misalnya jika pasien berasal dari kelas yang ekslusif seperti VIP dan kelas bangsal seperti kelas 2 dan 3, diharapkan ada konsep pelayanan perawat yang standar dengan melihat kondisi pasien yang berbeda. Semua tindakan pelayanan perawat dilakukan terus menerus demi untuk meningkatkan mutu layanan agar terjadi kepuasan pasien dan dimungkinkan akan membentuk.

Teradapat kesenjangan antara pengetahuan perawat tentang komunikasi terapeutik dengan tingkat kepuasan pasien dimana hasil wawancara dengan pasiean masih banyak perawat yang belum melaksanakan komnikasi teraupetik dengan bai sehingga tingkat kepuasan pasien masih kurang.

Berdasarkan studi pendahuluan yang dilakukan di Ruang Rawat Inap Cendana RS Tingkat III Wolter Mongisidi sebanyak 38 pasien dari hasil wawancara terhadap 10 (sepuluh) pasien yang dirawat didapatkan keluhan 6 pasien mengatakan puas dan 4 pasien mengatakan kurang puas dikarenakan adanya perawat yang kurang sabar, kurang senyum dan berbicara kasar. Apakah hal ini hanya merupakan persepsi pasien saja atau karena kurangnya pengetahuan dan kesadaran perawat untuk melakukan komunikasi terapeutik. Berdasarkan latar belakang tersebut maka penulis tertarik untuk menelitinya sehingga dalam penyusunan karya ilmiah ini penulis mengambil judul " Hubungan pengetahuan perawat tentang Komunikasi terapeutik Perawat terhadap Kepuasan Pasien Di ruang rawat inap RS Tingkat III Wilter mongisidi Manado Noongan.

\section{Metode}

Jenis penelitian yang digunakan adalah desain penelitian deskriptif analitik dengan rancangan Cross Secsional Study. Penelitian ini dilaksanakan di Rumah Sakit Tingkat III Wolter Mongisidi Manado pada bulan Agustus 2019. Populasi adalah seluruh pasien yang di Ruang Rawat Inap Di Ruang Cendana RS tingkat III Wolter Mongisidi Manado berjumlah 38 pasien, dengan tehnik total sampling.

Analisa data digunakan analisa Chi Square test. Dan instrument penelitian digunakan kuesioner pengetahuan perawat tentang komunikasi teraupetik dengan tingkat kepuasan pasien $1=$ Kadang-Kadang $2=$ Sering. Pada instrument variabel kepuasan pasien menggunakan skala likert. $1=$ Kurang Puas $2=$ Puas

Pengelolaan Data

1. Editing data

Editing data dilakukan agar seluruh data dapat diolah dengan baik sehingga, menghasilkan output yang merupakan gambaran jawaban terhadap pertanyaan penelitian.

2. Coding data

Coding data penelitian menterjemahkan informasi atau data yang diperoleh.

3. Entri data Entri data adalah kegiatan memasukkan data yang telah dikumpulkan dalam master tabel, kemudian membuat distribusi frekuensi sederhana. Selanjutnya dimasukkan kedalam uji SPSS untuk mendapatkan hasil uji dari pengetahuan perawat tentang komunikasi teraupetik dengan tingkat kepuasan pasien.

4. Melakukan teknik analisis Dalam melaksanakan analisis, khususnya terhadap data penelitian akan menggunakan ilmu statistik terapan yang disesuaikan dengan tujuan yang hendak dianalisis

Analisa Data

1. Analisis Univariat

Analisis ini dilakukan untuk mengetahui secara deskriptif hubungan dan faktor-faktor lain yang dianggap perlu dan berkaitan dengan 2 variabel (dependen dan independent) yang akan diteliti. Analisis univariat akan dipaparkan dalam bentuk disribusi frekuensi yang terdiri dari nilai frekuensi dan presentase.

2. Analisis Bivariat

Analisa ini bertujuan untuk mencari hubungan komunikasi terapeutik perawat dengan kepuasan pasien.Analisis data yang digunakan dalam penelitian ini yaitu analisis data deskriptif kuantitatif dengan menggunakan Uji Chi-Squaredengan nilai kemaknaan $\alpha 0,05$ atau $95 \%$. 


\section{Hasil}

1. Karakteristik Responden

a. Umur

Tabel 1. Distribusi karakteristik responden berdasarkan umur responden

\begin{tabular}{ccc}
\hline Umur & n & \% \\
\hline $20-30$ & 14 & 36,8 \\
$31-40$ & 18 & 47,7 \\
$>40$ & 6 & 15,8 \\
\hline Jumlah & 38 & 100 \\
\hline
\end{tabular}

Berdasarkan tabel 1, menunjukkan dari 38 responden (perawat) yang berumur $31-40$ Tahun menunjukkan yang terbesar yaitu $47,4 \%$ atau sebanyak 18 orang dan yang terkecil berumur $>40$ Tahun sebesar $15,8 \%$ atau sebanyak 6 orang.

b. Pendidikan

Tabel 2. Distribusi karakteristik responden berdasarkan pendidikan responden

\begin{tabular}{ccc}
\hline Pendidikan & n & \% \\
\hline SPK & 8 & 21,1 \\
D3 & 29 & 76,3 \\
S1 & 0 & 0 \\
Ners & 1 & 2,6 \\
\hline Jumlah & 38 & 100
\end{tabular}

Berdasarkan tabel2, dari 38 responden menunjukkan tingkat pendidikan responden terbanyak yaitu pendidikan D3 sebesar $76,3 \%$ atau sebanyak 29 orang dan yang paling sedikit yaitu pendidikan Ners sebesar 2,6\% atau sebanyak 1orang.

c. Masa kerja

Tabel 3. Distribusi karakteristik responden berdasarkan masa kerja responden

\begin{tabular}{ccc}
\hline Pendidikan & n & \% \\
\hline$<15$ Tahun & 16 & 42,1 \\
$>15$ Tahun & 22 & 57,9 \\
\hline Jumlah & 38 & 100 \\
\hline
\end{tabular}

Berdasarkan tabel 3, dari 38 responden menunjukkan responden dengan masa kerja lebih dari 15 tahun terbesar yaitu $57,9 \%$ atau sebanyak 22 orang.

2. Analisa univariat

a. Pengetahuan Tentang Komunikasi terapeutik

Tabel 4. Distribusi karakteristik responden berdasarkan pengetahuan komunikasi teraupetik

\begin{tabular}{ccc}
\hline $\begin{array}{c}\text { Pengetahuan tentang } \\
\text { Komunikasi Terapeutik }\end{array}$ & $\mathbf{n}$ & $\boldsymbol{\%}$ \\
\hline Kurang & 9 & 23,6 \\
Cukup & 5 & 13,2 \\
Baik & 24 & 63,2 \\
\hline Jumlah & 38 & 100 \\
\hline
\end{tabular}

Pada tabel 4 terlihat bahwa pengetahuan tentang komunikasi terapeutik kurang sebanyak 9 responden atau $23,6 \%$, pengetahuan tentang komunikasi terapeutik cukup sebanyak 5 responden atau $13,2 \%$ dan pengetahuan tentang komunikasi terapeutik baik sebanyak 24 responden atau $63,2 \%$. 
b. Kepuasan Pasien

Tabel 5. Distribusi karakteristik responden berdasarkan kepuasan pasien

\begin{tabular}{ccc}
\hline Kepuasan Pasien & n & \% \\
\hline Kurang Puas & 10 & 26,3 \\
Cukup Puas & 4 & 10,5 \\
Puas & 24 & 6,2 \\
\hline Jumlah & 38 & 100 \\
\hline
\end{tabular}

Pada tabel 5. diatas terlihat bahwa pasien yang merasa kurang puas sebanyak 10 responden atau $26,3 \%$, pasien yang merasa cukup puas sebayak 4 responden atau $10,5 \%$, dan pasien yang merasa puas sebanyak 24 orang atau $63,2 \%$.

3. Analisa Bivariat

Tabel 6. Hubungan pengetahuan tentang komunikasi terapeutik dengan kepuasan pasien di ruang cendana rs wolter mongisidi tingkat III manado

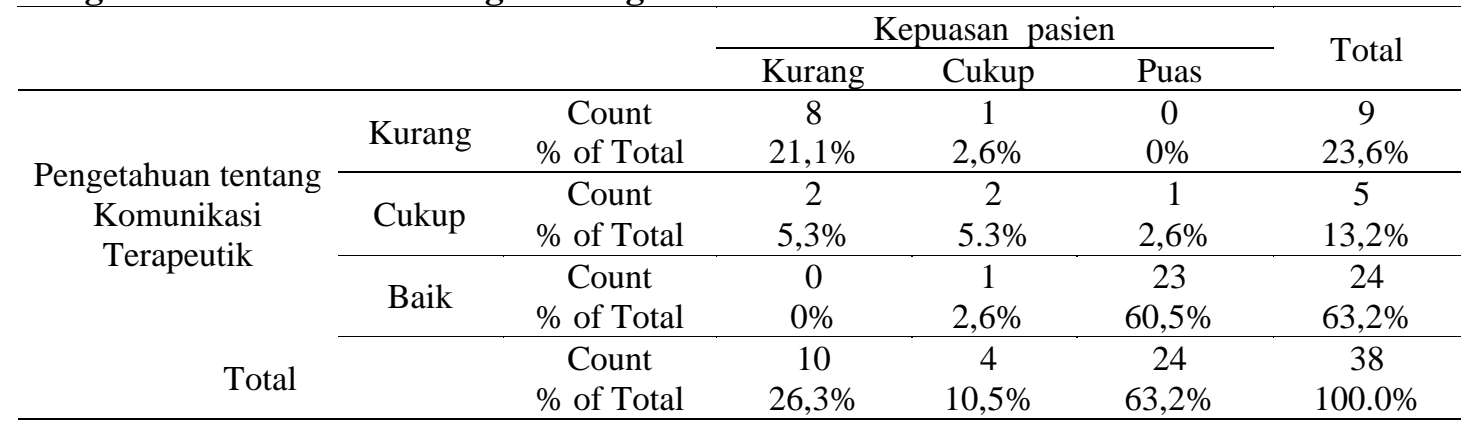

Pada tabel 6 terlihat bahwa jika pengetahuan tentang komunikasi terapeutik perawat kurang maka kepuasan pasien kurang sebanyak 23,6\% atau 9 orang, dan pasien yang merasa cukup puas sebanyak 1 orang atau $2,6 \%$, jika pengetahuan tentang komunikasi terapeutik perawat cukup maka kepuasan pasien yang kurang sebanyak 2 orang atau 5,3\%, pasien yang merasa cukup puas sebanyak 5,3\% atau 2 orang dan pasien yang merasa puas sebanyak 2,6\% atau 1 orang. Sedangkan pada pengetahuan tentang komunikasi terapeutik baik maka pasien yang merasa kurang puas $0 \%$, pesien yang merasa cukup puas sebanyak $2,6 \%$ atau 1 orang dan yang merasa puas sebanyak 23 orang atau $60,5 \%$.

Berdasarkan tabel che square dengan $\mathrm{df}=2$ dan taraf signifikansi $5 \%$ diperoleh $\mathrm{X}^{2}$ tabel sebesar 5,99. Oleh karena $\mathrm{X}^{2}$ hitung lebih besar dari $\mathrm{X}^{2}$ tabel maka dapat dinyatakan terdapat hubungan yang signifikan antara pengetahuan tentang komunikasi terapeutik dengan kepuasan pasien.

Berdasarkan data diatas hasil uji statistik Chi-square menunjukkan ada hubungan antara pengetahuantentang komunikasi terapeutik dengan kepuasan pasien, dengan nilai kemaknaan $(\alpha)=0,05$ melalui pengujian SPSS versi 16,0 didapatkan nilai signifikan $(P)=0,00$ yang lebih kecil dari $\alpha=0,05$ dengan demikian maka dapat dikatakan Ha diterima dan Ho ditolak. Saran dalam penelitian ini yaitu diharapkan lebih meningkatan pengetahuan perawat tentang komunikasi terapeutik kepada para pasien, karena dengan adanya komunikasi yang terapeutik pasien akan merasakan kepuasan sehingga proses kesembuhan pasien cepat dicapai.

\section{Pembahasan}

1. Pengetahuan Tentang Komunikasi Terapeutik

Hasil penelitian menunjukkan bahwa pengetahuan tentang komunikasi terapeutik kurang sebanyak 9 responden atau $23,6 \%$, pengetahuan tentang komunikasi terapeutik cukup sebanyak 5 responden atau 13,2\% dan pengetahuan tentang komunikasi terapeutik baik sebanyak 24 responden atau 63,2\%. Menurut Purwanto (2009) komunikasi terapeutik adalah komunikasi yang direncanakan secara sadar, kegiatannya mempunyai tujuan untuk kesembuhan klien. Menurut Roger, 1961 dikutif Arwani (2003) komunikasi terapeutik bukan merupakan apa yang dilakukan seseorang, tetapi bagaimana seseorang melakukan komunikasi itu dalam berhubungan dengan orang lain. Sedangkan menurut Mundakir (2010) komunikasi terapeutik adalah suatu pengalaman bersama antara perawat-klien yang bertujuan untuk menyelesaikan masalah klien.

Komunikasi terapeutik adalah komunikasi yang direncanakan secara sadar, bertujuan dan kegiatannya dipusatkan untuk kesembuhan pasien (Indrawati, 2012). Dalam pengertian lain mengatakan bahwa komunikasi terapeutik adalah proses yang digunakan oleh terapis memakai pendekatan yang direncanakan secara sadar, bertujuan dan kegiatannya dipusatkan pada klien. Stuart G. W. (2008) menyatakan bahwa 
komunikasi terapeutik merupakan hubungan interpersonal antara perawat dan klien, dalam hubungan ini perawat dan klien memperoleh pengalaman belajar bersama dalam rangka memperbaiki pengalaman emosional klien. Northouse, 2010) menyatakan bahwa komunikasi terapeutik adalah kemampuan dan keterampilan perawat untuk membantu klien beradaptasi terhadap stress, mengatasi gangguan psikologis, dan belajar bagaimana berhubungan baik dengan orang lain.

Perawat sebagai petugas yang selalu berhubungan dengan pasien harus memiliki banyak keterampilan, salah satunya adalah keterampilan Interpersonal, yaitu keterampilan dalam berkomunikasi dengan pasien (terapeutik).

2. Kepuasan Pasien

Hasil penelitian menunjukkan bahwa pasien yang merasa kurang puas sebanyak 10 responden atau $26,3 \%$, pasien yang merasa cukup puas sebayak 4 responden atau $10,5 \%$, dan pasien yang merasa puas sebanyak 24 orang atau $63,2 \%$.

Kepuasan pasien adalah memahami kebutuhan dan keinginan konsumen dalam hal ini pasien adalah hal penting yang mempengaruhi kepuasan pasien. Pasien yang puas merupakan aset yang sangat berharga karena apabila pasien puas mereka akan terus melakukan pemakaian terhadap jasa pilihannya, tetapi jika pasien merasa tidak puas mereka akan memberitahukan dua kali lebih hebat kepada orang lain tentang pengalaman buruknya.

Untuk menciptakan kepuasan pasien suatu perusahaan atau rumah sakit harus menciptakan suatu system untuk memperoleh pasien yang lebih banyak dan kemampuan untuk mempertahankan pasiennya.Namun upaya untuk perbaikan atau kesempurnaan kepuasan dapat dilakukan dengan berbagai strategi oleh perusahaan untuk dapat merebut pelanggan.Junaidi (2012) berpendapat bahwa kepuasan konsumen atas suatu produk dengan kinerja yang dirasakan konsumen atas poduk tersebut. Jika kinerja produk lebih tinggi dari harapan konsumen maka konsumen akan mengalami kepuasan.

3. Analisa Bivariat

Berdasarkan uji statistik che square dengan $\mathrm{df}=2$ dan taraf signifikansi $5 \%$ diperoleh $\mathrm{X}^{2}$ tabel sebesar 5,99 . Oleh karena $X^{2}$ hitung lebih besar dari $X^{2}$ tabel maka dapat dinyatakan tedapat hubungan yang significan antara pengetahuan tentang komunikasi terapeutik dengan kepuasan pasien.

Berdasarkan data diatas hasil uji statistik Chi-square menunjukkan ada hubungan pengetahuan tentang komunikasi terapeutik dengan kepuasan pasien dengan nilai kemaknaan $(\alpha)=0,05$ melalui pengujian SPSS versi 19,0 didapatkan nilai signifikan $(P)=0,00$ yang lebih kecil dari $\alpha=0,05$ dengan demikian maka dapat dikatakan Ha diterima dan Ho ditolak.

Komunikasi terapeutik merupakan cara efektif untuk mempengaruhi tingkah laku manusia dan bermanfaat dalam melaksanakan pelayanan kesehatan di Rumah Sakit, sehingga komunikasi ini harus dikembangkan terus-menerus (Kario, 1998). Hubungan antara perawat dan klien yang terapeutik bisa terwujud dengan adanya interaksi yang terapeutik antara keduanya, interaksi tersebut harus dilakukan dengan tahapan-tahapan baku interaksi terapeutik perawat klien, tahapan itu adalah tahap pre orientasi, tahap orientasi, tahap kerja dan terminasi (Stuart dan Sunden, 2011).

Pengukuran tingkat kepuasan pasien mutlak diperlukan, dalam upaya peningkatan mutu pelayanan kesehatan. Melalui pengukuran tersebut, maka dapat diketahui sejauh mana dimensi-dimensi mutu pelayanan kesehatan yang telah diselenggarakan dapat memenuhi harapan pasien (Pohan, 2002).

Wijono (2008) mengungkapkan kepuasan pelanggan rumah sakit atau organisasi pelayanan kesehatan lain atau kepuasan pasien dipengaruhi banyak faktor antara lain pendekatan dan perilaku petugas, mutu inlormasi, prosedur perjanjian, waktu tunggu, lasilitas umum yang tersedia, fasilitas perhotelan untuk pasien seperti mutu makanan, pengaturan kunjungan dan "privasi" outcome terapi dan perawatan yang diterima. Salah satu faktor untuk mempengaruhi kepuasan pasien adalah pendekatan dan perilaku petugas yaitu komunikasi terapeutik. Komunikasi terapeutik merupakan hal yang sangat penting bagi perawat untuk mendukung proses keperawatan yang meliputi pengkajian diagnosa keperawatan, perencanaan, pelaksanaan dan penilaian. Peran komunikasi sebagai sarana untuk menggali kebutuhan pasien.

Pada era globalisasi, pelayanan prima merupakan elemen utama di rumah sakit dan unit kesehatan.Rumah sakit dituntut untuk memberikan pelayanan kesehatan yang memenuhi standar pelayanan yang optimal.Hal tersebut sebagai akuntabilitas rumah sakit supaya mampu bersaing dengan Rumah Sakit lainnya.Komunikasi terapeutik adalah komunikasi yang direncanakan secara sadar, bertujuan dan kegiatannya dipusatkan untuk kesembuhan pasien (Indrawati, 2012). Dalam pengertian lain mengatakan bahwa komunikasi terapeutik adalah proses yang digunakan oleh terapis memakai pendekatan yang direncanakan secara sadar, bertujuan dan kegiatannya dipusatkan pada klien. Stuart G. W. (2008) menyatakan bahwa komunikasi terapeutik merupakan hubungan interpersonal antara perawat dan klien, dalam hubungan ini perawat dan klien memperoleh pengalaman belajar bersama dalam rangka memperbaiki pengalaman emosional klien. Northouse, 2010) menyatakan bahwa komunikasi terapeutik adalah kemampuan dan keterampilan perawat untuk membantu klien beradaptasi terhadap stress, mengatasi gangguan psikologis, dan belajar bagaimana berhubungan baik dengan orang lain. 
Rumah sakit adalah bentuk organisasi pelayanan kesehatan yang bersifat komprehensif, mencakup aspek promotif, preventif, kuratif dan rehabilitatif, serta sebagai pusat rujukan kesehatan masyarakat (Anonim, 2011).

Kepuasan pasien tergantung pada kualitas pelayanan. Pelayanan adalah semua upaya yang dilakukan karyawan untuk memenuhi keinginan pelanggannya dengan jasa yang akan diberikan. Suatu pelayanan dikatakan baik oleh pasien, ditentukan oleh kenyataan apakah jasa yang diberikan bisa memenuhi kebutuhan pasien, dengan menggunakan persepsi pasien tentang pelayanan yang diterima (memuaskan atau mengecewakan, juga termasuk lamanya waktu pelayanan).Kepuasan dimulai dari penerimaan terhadap pasien dari pertama kali datang, sampai pasien meninggalkan rumah sakit. Pengetahuan perawat yang baik akan sangat mempengaruhi kominikasi teraupetik yang baik terhadap pasien dengan demikian akan mendukung tercapainya tingkat kepuasan pasien terhadap pelayanan yang diberikan oleh medis dan para medis sehingga proses kesembuhan pasien lebih cepat dicapai.

\section{Kesimpulan}

1. Berdasarkan hasil penelitian terlihat bahwa lebih banyak responden yang memiliki pengetahuan tentang komunikasi terapeutik baik dari pada pengetahuan tentang komunikasi terapeutik kurang dan cukup.

2. Entri data Entri data adalah kegiatan memasukkan data yang telah dikumpulkan dalam master tabel, kemudian membuat distribusi frekuensi sederhana. 4. Melakukan teknik analisis Dalam melaksanakan analisis, khususnya terhadap data penelitian akan menggunakan ilmu statistik terapan yang disesuaikan dengan tujuan yang hendak dianalisisBerdasarkan hasil penelitian terlihat lebih banyak responden kepuasan pasien yang puas dari pada kepuasan pasien yang kurang dan cukup.

3. Terdapat hubungan pengetahuan tentang komunikasi terapeutik dengan kepuasan pasien di ruang Cendana RS Tingkat III Wolter Mongisidi Manado.

\section{Saran}

Penelitian ini sangat bermanfaat dalam upaya memberikan informasi kepada perawat tentang upaya peningkatan pengetahuan perawat sekaligus perawat melakukan komunikasi teraupetik dengan baik sehingga pasien merasa puas dengan demikian proses kesembuhan pasien lebih cepat.

\section{Referensi}

Aswar, 2012. Perilaku Carring perawat dalam pelayanan kesehatan pada pasien di Rumah sakit PT Gramedia ,Jakarta

Arwani, 2003.Komunikasi teraupetik perawat dengan tingkat kepuasan pasien di Pusat pelayanan kesehatan, Gajahmada, Jakarta.

DepKes RI. 2016. Pendekatan pelayanan kesehatan oleh petugas kesehatan dalam pelayanan prima.

DinKes Propinsi Sulut, Pelayanan Prima yang berbasis masyarakat yang mengutamakan kesembuhan pasien.

Endang, 2015.Terapi komunikasi dalam pelayanan kesehatanoleh petugas kesehatan.

Harun, Analisis Kepuasan Pasien Rawat Inap terhadap Mutu Pelayanan RumahSakit Nirmala Suri Sukohardjo dengan Methode Servqual, Tesis Kajian Administrasi Rumah Sakit, FKMUI, Depok, 1994.

Ingerani, dkk,.Tingkat Kepuasan Pelanggan Terhadap Pelayanan Kesehatan di Propinsi DKI Jakarta. Laporan Penelitian Kerjasama Dinkes Prop. DKI Jakarta dan Badan Litbangkes Depkes RI, Jakarta, 2002.

Iswardono, Analisa Regresi dan Korelasi, BPFE, Yogyakarta, 2001

Indrawati, 2012 Komunikasi teraupetik untuk kesembuhan pasien rawat inap di Rumah Sakit.

Karion, 2012.Hubungan Komunikasi antara perawat dan pasien di Pusat Pelayanan Kesehatan.

Keliat, Budi Anna. 1992. Hubungan Terapeutik Perawat-Klien. Jakarta: Buku Kedokteran EGC. 
Mundakir. 2006. Komunikasi Keperawatan Aplikasi Dalam Pelayanan. Yogyakarta : Graha Ilmu

Parasuraman, A Zeithaml, Valerie A.dan L Berry, Delivering Quality Service, The Free Press A Divission of Mac Millan inc, New York, 1991.

Potter, P.A \& Perry, A.G. (1993) Fundamental of Nursing Concepts, Process and Practice.Thrd edition. St.Louis: Mosby Year Book

1999. Fundamental Keperawatan. Jakarta: EGC

Purwanto, Heri. 1994. Komunikasi Untuk Perawat. Jakarta: Buku Kedokteran EGC.

Sarkasih, 2016.Jurnal Penelitian hubungan komunikasi teraupetik perawat dengan tingkat kepuasan pasien beserta dengan kuesioner penelitian.

Sugiyono, Prof. Dr. Metode Penelitian Kuantitatif dan $R \&$ D. Bandung : CV ALFABETA

Supranto J, Pengukuran Tingkat Kepuasan Pelanggan Untuk Menaikkan Pangsa Pasar, Rineka Cipta. 2001.

Suryani. 2005. Komunikasi Terapeutik :Teori dan Praktik. Jakarta: Buku Kedokteran EGC.

Stuart.G.W. \& Sundeen.S.J.(1998) . Buku Saku Keperawatan Jiwa.Alih Bahasa: Achir Yani S. Hamid. ed ke-3. Jakarta, EGC 